\title{
Monetizing and Growing the Assets of Higher Education Institutions
}

\author{
Guilbert C. Hentschke
}

\author{
"The use of money is all the advantage there is in having it." \\ Benjamin Franklin. United States \\ 17 Jan 1706 // 17 Apr 1790
}

\section{Introduction}

Monetizing assets of higher education institutions (HEIs) includes virtually all that a HEI can work with to improve itself. This perspective represents a newer, broader (still slightly controversial) view of assets that includes people [1], 2. "Improving itself" takes many forms, but ultimately is reflected in money-from growing net income annually on the way to growing net assets over the years. (Assets reported on typical HEI financial balance sheets will always be referred to here as "net assets" or the difference between assets and liabilities; otherwise "assets" here means "everything" an HEI owns or has use of.) HEI work is reflected in money, or, more accurately, in money that has been put to work. To paraphrase Franklin, "How HEIs monetize their assets is all the advantage there is in having them."

To monetize assets is to raise resources, invest them in assets, and to transform them in such a way as to generate increased income and grow net assets. This "raising and investing" perspective of asset monetization encompasses all HEI work, including "advancement", "retrenchment", "faculty development", "course and program development", "student services", "technology transfer", "alumni relations", "pursuing alternative revenue sources", "budgeting", "debt and liquidity management", and "sustainability", as well as topics that are more abstract and less overtly financial, such as "brand enhancement", "talent management", "innovation" and "capacity building", "logistics", "governance", and "threat management".

G. C. Hentschke ( $\square)$

University of Southern California's Rossier School of Education, Los Angels, CA, USA

e-mail: ghentsch@usc.edu
All of these activities are at the heart of making each HEI "better", and all can be incorporated within the six broad categories that HEIs use to monetize their assets: (1) wringing out resources to invest; (2) borrowing resources to invest; (3) trading resources to invest; (4) soliciting resources to invest; (5) selling monetized assets; and (6) creating new assets.

Asset monetization presumes an intimate working relationship between the "academic" and "business" sides of each HEI. This, however, gets ahead of the story. The story begins with portraying HEIs as organizations that, like so many others, seek to raise more revenues than expenditures and to grow more assets than liabilities - all in a rapidly changing, potentially threatening, turbulent environment.

\section{Higher Education Institutions as Economic Entities}

Extraordinary challenges require HEI leaders to pay ever greater attention to the economic dimensions of their institutions, especially to the productivity of assets that each HEI currently owns, controls, or substantially influences. (Worthy institutional goals are only as achievable as the HEI is financially viable.) Financial challenges, mixed with opportunities, abound. Take, for example, the growing belief of individuals and governments that "the more you learn, the more you earn" which drives increased demand for HEI services, fostering growth while also straining capacity and resources. A closely related HEI challenge/opportunity is over-reliance on legacy business models where unmanaged cost structures are driving up operating costs and prices faster than revenue streams can support. "Quick fixes" to 
increase income and reduce expenditures are becoming insufficient.

Increasing global competition among HEIs forces each to enhance the reach and yield of its marketing efforts to grow consumer interest in its product and service offerings. Non-competitive HEIs are retrenching, merging, restructuring, or closing in greater numbers [3], as many as 200 U.S. HEIs over the coming years [4]. External shocks to higher education associated with COVID-19 are rapidly accelerating financial pressures from all sides, including the most financially healthy and academically prestigious HEIs [4]. In the U.S. alone, a $15 \%$ drop in total enrollment is predicted, and no HEI will be untouched.

Long before this pandemic occurred, traditional sources of HEI revenue such as general appropriations from state and national governments, have been declining (as a proportion of HEI income), forcing HEIs to pursue and grow alternative revenue streams, e.g., from other departments of government, households, donors, businesses, foundations, and communities. Even countries with recent histories of generous support for higher education are providing guidance to their HEIs on how to deal with "increasing independence" (a euphemism for "reductions in future financial appropriations"), signalizing further limitations of governmental support [5], 6 .

Maintaining balanced budgets is being replaced by survival and growth as top of mind goals [7]. Moody's (financial analysts) argues that HEIs need to grow top line (total) revenue by at least $3 \%$ annually, just to remain financially stable [8]. For an HEI to achieve a true "transformation" from its current circumstances requires, per consulting firm McKinsey and Company, at least a $20 \%$ net surplus of revenues over expenditures, which cannot be achieved by efficiencies alone [8].

While the "core" mission on the academic side needs to thrive, it cannot succeed without the financial sophistication and support of the business side of the HEA. Yet, distrust continues to exist between the two (see, for example, [9]), due in part to opaque traditional HEI financial reports which result in piecemeal recognition and resolution of both problems and opportunities.

Yet, these same financial records serve as a starting point for revealing broad challenges and opportunities, including those that reflect changes in financial status at different points in time (balance sheets). There, assets (what the HEI owns) are arrayed against liabilities (what it owes) and the difference (net assets) does provide a crude measure of overall size and wealth at a single point in time. The positive difference between assets and liabilities, ("fund balance" or "equity" or "retained earnings", depending on the HEI) represents one measure of how well off the HEI is at that point in time. (Short run performance over time is reflected in income and cash flow statements.) Long run performance is better reflected in comparisons of these changes in net assets over years and decades [10]. Between 2015-16 and 2017-18, for example, University of Oxford's net assets grew over $23 \%$ from 3.0 billion to 3.7 billion pounds sterling [11, p. 23]. Despite the ups and downs of a given year, Oxford's wealth, as reflected in net asset changes, was growing at an impressive pace, not unlike those at Northwestern University between 2001 and 2019 [12], 13. (On occasion net assets can and do decline from one year to the next; reasons range from opportunistic investments to emergency asset sell offs.) HEIs generally succeed in growing net assets over the years, but some are much more successful, and others much less successful, than the rest, due to (1) the size and composition of a HEI's assets, (2) the managerial expertise applied in monetizing its assets, and (3) changes in market conditions affecting demand for those assets.

\subsection{Assets - What They Consist of}

The assets of a HEI are vastly more than the buildings it owns, although buildings and land provide a physical, concrete point of departure. In fact, assets include:

. . a any] resource with economic value that an individual,
corporation, or country owns or controls with the expectation
that it will provide a future benefit. Assets are . . bought or
created to increase a firm's value or benefit the firm's operations.
An asset can be thought of as something that, in the future, can
generate cash flow, reduce expenses, or improve sales, regard-
less of whether it's manufacturing equipment or a patent. [14,
p. 1] (emphasis added)

Besides buildings, the biggest and most consequential HEI assets consist of people, both faculty and staff, which is usually an HEI's biggest expense item and its biggest investment.

People can be assets because of the value they bring to a relationship or organization. Things which are assets have value for the owner because they can be converted into cash. Cash on hand is also considered an asset. [15] (emphasis added)

Buildings, land, money, and people head an HEI's asset list, but are only a fraction of the variety of assets that any one HEI is likely to own or control (see Exhibit One).

\section{Exhibit One: Potential Assets of Higher Education Institutions*}

\section{Tangible Assets}

- Buildings

- Cash on deposit

- Cash on hand

- Certificates of deposit or CDs 
- Commercial paper

- Corporate bonds

- Corporate stock

- Debentures held

- Equipment

- Federal agency securities

- Federal treasury notes

- Guaranteed investment accounts

- Inventory

- Land

- Loans to members of insurance trusts systems

- Loans receivables

- Marketable equity securities

- Marketable securities

- Money market funds

- Mortgages (receivable) held directly

- Mutual funds

- Notes receivables

- Repurchase agreements

- "Restricted" cash and investments

- Savings accounts

- Share of funds in governmental investment accounts or pools

- State and local government securities

- Time deposits

- Warrants (to purchase securities) Accounts receivable.

\section{Intangible Assets}

- Blueprints

- Bonds

- Brand names

- Brand recognition

- Broadcast licenses

- Buy-sell agreements

- Chemical formulas

- Computer programs

- Computerized databases

- Contracts

- Cooperative agreements

- Copyrights

- Customer relationships

- Designs \& drawings

- Distribution rights

- Development rights

- Distribution networks

- Domain names

- Drilling rights

- Easements

- Engineering drawings

- Environmental rights

- FCC licenses
- Film libraries

- Food flavorings and recipes

- Franchise agreements

- Goodwill

- Historical documents

- Joint ventures

- Laboratory notebooks

- Landing rights

- Licenses

- Loan portfolios

- Location value

- Management contracts

- Manual databases

- Manuscripts

- Medical charts and records

- Methodologies

- Mineral rights

- Musical compositions

- Natural resources

- Patents

- Permits

- Procedural manuals

- Product designs

- Property use rights

- Proprietary technology

- Royalty agreements

- Schematics and diagrams

- Securities portfolios

- Security interests

- Shareholder agreements

- Solicitation rights

- Supplier contracts

- Technology sharing agreements

- Title plants

- Trademarks

- Trade secrets

- Trained and assembled workforce

- Training manuals

- Use rights-air, water, land.

*Source: Examples of Assets, Your Dictionary, accessed 2/17/20 from https://examples.yourdictionary.com/ examples-of-assets.html.

Costs of maintaining an asset can be tracked, but its overall impact on revenues and the value it adds to the HEI are often difficult to measure objectively. Beautifully manicured campus grounds and Nobel Laureate faculty are both examples of assets that create value, albeit imprecise (even if costs can be measured precisely). Buildings, land, and stock certificates are tangible assets, easy to distinguish, but less tangible assets, such as a trained and assembled work force, HEI brand recognition, geographic location, star faculty, 
stakeholder relationships, even procedural manuals (academic policies and practices, course syllabi), and regional alumni chapters, are more difficult to measure monetarily but are no less valuable.

HEI assets then include much more than those found in typical HEI financial statements, and their value is very imprecisely reflected in those statements. Some assets, e.g., equipment, tend to lose some of their value over time, even as others, e.g., land, may increase. Assets of declining value get written down. Additional investments in assets may preserve or enhance their value though added investment or monetization. Or they may not.

Treating HEIs as bundles of assets to be monetized requires "placing bets" when pulling resources from some sources to invest in others. Elements of uncertainty and risk go hand in hand with the possibility of enhancing net revenues and growing net assets. The fundamental leadership challenge is how best to monetize all of its assets-not whether to but how effectively to.

Over the long run HEIs increasingly distinguish themselves from each other by the degree to which they have increased their net assets. (A counter argument often heard is that HEIs distinguish themselves from each other by pursuing distinctiveness or uniqueness, but HEIs with roughly the same quantum of net assets are more similar to each other than different.) Some HEI financial analysts argue that growth in net assets should be about $3-4 \%$ above the rate of inflation on average [16]. HEI net assets in this view represent a dynamic, comprehensive measure of long run HEI performance, not just a listing of balance sheet items called "assets".

\subsection{Monetizing Assets-What Organizations Do with Their Assets}

Monetization is similar for a given asset across different industries. Mineral rights, for example, are monetized in roughly similar fashion regardless of whether they belong to a mining company or to a university. Yes, asset monetization differs between the mining and higher education industries [17]; in one, most of the assets are underground and very tangible, while in the other assets are mostly above ground and are intangible as well as tangible. In both industries, however, converting assets into cash requires material investments and sometimes multiple sources of financial capital to monetize them.

Either way, asset monetization requires the exercise of managerial expertise. Assets, by themselves do not make money; they must be monetized or "put to work" to generate net revenue productively. Monetization entails a figurative "handshake" between wringing money out of some assets (both figuratively and through sales) and investing money in others. Historically, monetizing assets largely referred only to selling off or liquidating them in such a way that generated cash. Today, "asset" includes assets such as "human capital", "brand", "operating policies", "operational procedures", "reputation" and the like.

Monetization transactions can also be more complex and include multifaceted exchanges, for example, sale-leasebacks, guaranteed purchase agreements, joint venturing, and subsidized access to capital. For the HEI these transactions amount to a conversion: "converting an asset (anything you own) into legal tender (money)" [18]; or "convert[ing] any event, object or transaction into a form of currency or something with transferable value" [19]; or "turning a non-revenue-generating item into cash, essentially liquidating an asset or object into legal tender [20].

Monetizing here involves converting a good or service into money, including efforts to convert enhanced goods or services into more money. Because most monetization efforts require added investments to realize monetary gains, efforts to raise investment capital-through cost-saving, debt, gifts, etc. - are intimately associated with most monetizing initiatives.

\subsection{Tracking Asset Monetization-Financial Reports and Their Limits}

Financial structures, protocols, and analytics in higher education are neither highly sophisticated nor uniformly accepted and applied [9], 21 22, thereby limiting the feasibility of formulating viable asset monetizing initiatives and of determining their impacts. Some may be formally captured by routine financial records, but most are not. As an illustration, the sale of a building is sufficiently large and self-contained that evidence of the sale, both what is sold and what is gained, can be readily formulated from existing data. On the other hand, the financial impact of the long run substitution of instructors for tenure track faculty, including what is gained and lost, is not reported and difficult to estimate, even to formulate.

Like balance sheets, income statements are limited in value: they provide necessary but not sufficient financial information to inform decisions about the flows of funds over time to, from, and within HEIs. Categories of expenditure, such as "instruction," "research and public service", auxiliary expenses", and "academic support, student services, and institutional support" are too crude and cannot help financially inform decisions about which instructional programs or student services should be pared back, enhanced, or better targeted. Similarly, typically broad revenue categories, e.g., government grants, contracts, and appropriations, tuition and fees, investments, and auxiliary enterprises are insufficient to identify which assets, with 
added investments, could yield greater net revenues. Unfortunately, the trend in HEI financial reporting is toward less, not greater, detail [21]. Without more customized financial analytics, it is difficult to determine which assets to monetize and what the financial impact of such monetization is likely to be [23]. The relatively opaque and idiosyncratic nature of university systems of accounting and reporting limits broad-based understanding of university fiscal health and leads to distrust, especially by faculty and staff [22].

The measuring problem goes beyond lack of detail. First, the financial sizing and impact of some of a HEIs most important assets, including its people, cannot be measured without factoring in extensive uncertainty. The assets of brand recognition, brand loyalty, faculty quality, customer satisfaction, and goodwill, are very important both in their own right and in the value they add to other HEI assets such as enrollment demand and alumni donations, but it is difficult to even estimate, let alone price, their probable impact. (Being an "experience good" higher education is inherently difficult to "comparison shop" against other HEIs, and therefore "reputation" is even more important than in many other industries.)

Second, long run impacts are difficult to gauge in part in part because new monetization decisions are made on top of earlier ones. Many assets already enjoy some level of historical monetization and derive their current value in part from earlier decisions to invest and market them, and monetization decisions are often conflated with routine "maintenance" or annual budget replacements. Many "maintenance" decisions have unintended consequences. For example, faculty assets are replenished each year as a part of natural turnover, but intentional changes in faculty investment and their impacts are seldom recognized. Yet, across HEIs, for example, a 10-point increase in the percentage of full-time faculty not in tenure-track positions was found to be associated with a 4.4 percentage point reduction in graduation rates (at public masters-level institutions). Would HEI senior management consciously decide to move faculty off the tenure track to save money, if it knew it would also cost a $4.4 \%$ reduction in graduation rates? Probably not, but the (easily measured) difference in average salaries between full-time lecturers and assistant professors at these institutions was over \$10,000 a year (2009-2010 data) [24]. At the same time, HEIs that invest more per capita in faculty face less faculty turnover, especially in the junior ranks [24]. Is it worth investing more in faculty "quality" to reduce faculty turnover or to increase student retention? Alternatively, is it worth the obvious savings of hiring less expensive faculty when it seems to increase student attrition rates? Without detailed analytics the answer is not clear. Typical financial reports are not designed to provide useful information on incremental changes in asset investments, although a wide variety of useful financial metrics exist and have been applied on an ad hoc basis (see, for example, [25]).

Third, market conditions may evolve over time, materially changing the potential value of present and future monetizing initiatives. One widely recognized illustration is the 1988 Bayh-Dole amendment [26] which increased the potential value of university research to HEIs, entitling them to the financial benefits of the research they generated. This led to the growth of "technology transfer" departments in about 400 of the most research-intensive U.S. universities [27]. From that year on, the potential market value of research and development efforts at some HEIs increased, followed by increased investments in research-anddevelopment infrastructure (assets).

Asset monetization is often a recurring, rather than one-time, set of decisions, and is influenced in part by changes in market conditions, which require customized or "transaction specific" analytics (reports) in order to make informed monetization decisions. This resembles the framework of budget preparation where revenues and expenditures are reset annually, but it differs from typical budgeting in two respects. One, monetization initiatives cut across departmental (traditional budgetary) lines. Two, they reflect explicit, incremental investments in - and expected payoffs from-some assets and not others.

\section{The Six Asset Monetization Tactics of Higher Education Institutions}

All work in higher education is associated with one or more of only six broad forms of monetization tactics. "Work" here includes: recruiting and housing students, staffing, offering and teaching courses, collecting tuition and related revenues, conducting research, building, maintaining, upgrading, and occupying buildings, recruiting, deploying and managing faculty and staff, cultivating and soliciting potential donors, creating and hosting cultural and athletic events, creating and distributing a perpetual stream of HEI communications, keeping track of expenditures and revenues made by hundreds or thousands of individuals, and more - a very broad umbrella. In each HEI, these tactics entail pulling resources from some assets and applying (investing) them in other assets.

A foundational presumption of this chapter is that variations of all six tactics are integral to each HEI and to an extent are interdependent. At the same time, given each HEI's unique bundle of assets and circumstances, its monetizing behavior is idiosyncratic and context dependent. The smallest HEIs are about $1 / 1000$ the size of the largest HEIs. They also range from very wealthy to very poor financial health. Existing HEIs are going out of business and new 
HEIs are being created with increasing frequency, while still others are steadily growing their net assets.

What has evolved, despite these differences, are similar asset monetization specializations within HEIs. Some have become commonly recognized organizational entities, e.g., departments of advancement, offices of technology transfer, admissions offices, alumni relations, and business services, student housing. Others take the form of one-off and more comprehensive initiatives undertaken by senior management, e.g., strategic planning, long-range planning, retrenchment, capital campaigns, ad hoc task forces, and, recently, COVID-19 Responses. Asset monetization is reflected in six broad forms across these commonly recognized organizational entities and initiatives: (1) wringing out resources to invest; (2) borrowing resources to invest; (3) trading resources to invest; (4) soliciting resources to invest; (5) selling monetized assets; and (6) creating new assets.

All six tactics reallocate capital from presumably lower performing assets to hopefully higher performing assets, i.e., those which show promise of yielding increases in net revenues and, over a longer period, increases in net assets. Estimates of the costs and benefits of asset monetization include those which can be measured in financial terms as well as those which are difficult to measure financially or even to quantify. All monetization initiatives have market consequences, positive, negative, or both, due to factors such as population demographics, availability of information analytics, and changes in transaction costs [28].

\section{1 "Wringing Out" Resources to Invest: Liquidation, Cost Reduction, and Efficiency Promotion}

Efforts to extract resources from current assets focus more attention on freeing up resources than on reinvesting freed up resources. The unstated use of most cost reduction initiatives is "to balance the budget", which, while important, is not so much an investment decision as a survival necessity.

\subsubsection{Cost Reductions to Balance the Budget}

The early, more limited, use of the term "asset monetization" directly applies here: converting assets to money by selling off the asset (liquidation), reducing the costs associated with maintaining and operating the asset (cost reduction), and seeking to achieve cost reductions without impairing asset functioning (efficiency promotion).

Concrete examples illustrate this efficiency perspective. The Ohio State University monetized its ("multi-billion dollar") parking facilities by turning over control to a private corporation under conditions of a long-term lease, complete with an upfront payment to the university and a period of no fee increases for parking [29]. The business model of the private corporation likely included lower operating costs than under Ohio State as well as increases in fees after the moratorium ended. Without these opportunities to recoup its investments, the corporation would not have been interested. In return, Ohio State gained ready access to near-term cash without impairing the functioning of its parking structures.

Monetized assets can bring new revenue to the table not only from the outside (per the Ohio State example) but also by reducing operating its own operating expenses, as at nearby Kent State University. Kent State closed its 18-hole golf course and club house, in effect mothballing the property for some future use while, by doing so, eliminating the half-million dollar per year operating loss from its budget. The "higher use" of the freed-up resources is not specified, but operating costs were cut immediately [29].

\subsubsection{Costs Incurred as Well as Costs Saved by Economizing}

Too often the tactics of cost reduction, efficiency promotion, and liquidation are portrayed as unfortunate ends in themselves, unconnected to any presumed benefits from monetizing - inflicted on the HEI to the detriment of morale and ipso facto with reduced service quality. The following one-sided lament is illustrative.

[HEI economizing measures] constitute a special kind of "relative deprivation"-removing or charging for things that were previously free or less expensive. Such economies . . . . are symbolic of a general tightness and meanness and perhaps signify degradations of employees who have professional or quasi-professional expectations. This effect is one of a larger range of consequences that arise when administrative decisions are guided solely by economic or managerial considerations without taking into account important human dimensions [30] (emphasis added).

Frequently overlooked in these characterizations are the less visible benefits associated with the use of those resources that are freed up, i.e., how they are redeployed as investments in more highly valued assets, including people. The most visible parts of efficiency-producing tactics are the cuts or reductions, but only when linked to reinvestments of those resources into other assets does a fuller asset monetization picture emerge.

Wringing money from assets can vary greatly in feasibility ("low hanging fruit" to "holy grail") and materiality ("chump change" to "home run"). See the list of money wringing tactics in Exhibit Two, collected from HEIs by the National Association of College and University Business Officials. 
Exhibit Two: Initial Thoughts On Wringing Out Resources*

\section{Information Technology}

Dim the brightness of computer monitors.

Keep PCs a year longer before replacing them.

Share training on administrative software with similar institutions.

Use a third party for hosting your server, which could save a staff position.

Switch to virtual servers.

\section{Education and Research}

Increase general faculty workload.

Require every administrator with a master's or doctoral degree to teach a course.

Find new classrooms with larger seating capacity and increase productivity by increasing class size.

Suspend or close: all undergraduate minors; graduate and undergraduate special-emphasis programs; up to $25 \%$ of all undergraduate majors; nonprofessional master's/doctoral programs that are not signature programs or not ranked among the top 50 in the nation.

Ongoing review of key student affairs programs to ensure retention.

Examine decentralized and specialized student affairs programs.

Scrutinize faculty space allocation.

Examine academic programs with small participation.

Review all centers and institutes. Demonstrate they are serving the university's core mission.

\section{Personnel}

Ask the president to forgo a salary increase; ask the president and other top administrators to take a salary cut.

Reward performance with a one-time bonus instead of increases to base salary.
Reduce retirement plan contributions (zero effect on salaries).

Offer employees temporary or partial leave without pay but with full benefits.

Pool support staff members in clusters of four and five departments.

Consolidate common functions that have become dispersed (e.g., advancement activities).

Shut down between Christmas and New Year's Day to save utilities; ask employees to either take leave or comp time.

Implement 4-day week with extended daily hours for summer and operate only required buildings on Fridays (dining halls, residence halls, health center, etc.).

Conduct analysis to closely examine how each staff person's work contributes to the institution's mission.

Defer state approved salary increases for nine months.

Budget for zero new positions, zero departmental budget increases.

Closely examine all vacancies before filling.

Freeze hiring of temporary employees, consultants and independent contractors.

Consider voluntary retirement incentive plans.

Approve travel based upon funds and reduce travel.

Freeze salary levels for administrators making more than $\$ 150,000$, while giving modest raises to staff on the lower end of the pay scale.

Reduce all salaries by a certain percentage.

\section{Benefits}

Examine tuition remission programs for faculty and staff.

Examine health care benefit levels of spousal and dependent health care coverage.

\section{Finance}

Discontinue printing or mailing paper student registration receipts. 
Collaborate with other institutions to share faculty members, facilities, registration and records functions, security, and parking.

Reduce debt-service payments by renegotiating long-term debt, seeking a lower interest rate, extending the term of the loan, or changing banks.

Require direct deposit for employee and student payroll.

Use purchasing cards to better track procurement.

Use cooperatively bid contracts to reduce spend.

Hold off for now on financing any new debt.

Ask donors to accelerate pledge payments.

Employ mid-year budget reductions.

Plan for budget cuts at 3-10\% levels.

Sell off assets.

\section{Facilities}

Recommend computer, printer, monitor, light, and accessory item shutdowns.

Consider a longer winter break to save energy.

Add outside lighting timers and classroom light timers.

Eliminate excess storage facilities for food and supplies.

Switch to compact fluorescent bulbs.

Purchase energy efficient equipment when new equipment is needed.

Lease prime ground-floor spaces in campus buildings to retailers, professional firms, independent nonprofit organizations, and other revenue providers.

Increase rental revenues by encouraging local entities to use campus recreation areas, music venues, meeting rooms, etc.

Close and lease remote campuses and unused buildings.

Fill office, buildings-and-grounds, and custodial staff positions with student workers who will earn tuition credits.
Lock in utility contracts now for the next few years while the price of energy is significantly reduced compared to just months ago.

Consolidate classrooms and schedule all summer classes in only two buildings to save on utilities and custodial staff in all other academic buildings.

Clean buildings at night when the job can be done faster.

Slow construction projects and reexamine capital projects that can be delayed or deferred.

\section{Other}

Review of property risk management with outside consultant and hire a certified risk manager.

Negotiate with service providers for lower management fees.

Establish a committee to collect and review cost-saving suggestions.

Establish an ongoing independent campus-wide task force to find operating savings with three-year horizon.

*Source: National Association of College and University Business Officials, accessed 8 March, 2020, from: https://www. missouristate.edu/assets/longrangeplan/cost_reduction_strate gies.pdf

Increasingly cost reduction is framed as only one side of a necessarily two-sided coin-cost reduction and revenue enhancement. Budget reductions pull resources from existing operations and assets, and budget reallocations include finding new ways to fund existing operations and invest in other assets.

Reallocations often yield improvements in net income, but even material changes and their financial impacts are not always reflected in traditional financial documents. For example, consider the difficulty of determining the financial value of eliminating and consolidating small or moribund academic programs without knowing the costs and revenues associated with these programs and the costs and revenues associated with new departments, programs, or courses. The impact can be major, but don't look for it in traditional financial reports or budgets. Over a 15-year period The Pennsylvania State University closed or merged 244 academic programs and majors, including 14 academic departments [31], 32. The net financial impact of pulling resources from these and investing in new initiatives may be great, but how great is not clear from available data. 
"Savings" also accrue when an administrative unit is made to become more self-sufficient, i.e., paying for its operation from the revenue it generates instead of from appropriations from above. Such was the case with Penn State's technology transfer office. Other cost reduction initiatives there have been more amenable to detailed cost and revenue tracking, such as in energy procurement $(\$ 11.8$ million annual savings), voluntary retirement programs (\$14.4 million one-time savings), and negotiated contracts with new third-party administrators for health care and prescription plans (\$70.9 million over 3 years).

The multi-year effects of both reducing operating costs and capping expenditure increases can be problematic, setting up larger issues in the future [33]. For example, at one HEI under new cost control procedures, hiring managers were asked to consider creative alternatives to filling vacant positions to determine if the essential functions of the position could be accomplished in a more efficient and effective manner without hiring a replacement. Those managers did not benefit from these efficiencies, because their departments did not benefit from any saved money. Instead, they had to bear the increased per-capita load of work. With these negative incentives in place, this "cost saving" initiative had little positive impact.

\subsubsection{Future Look: Closer Ties to Investments and More "Routine" Cost Controls}

HEIs are increasingly routinizing cost controls by investing more resources in digital information systems that more effectively track spending behavior across departmental units. These newer systems encompass the broad area of "spend management" which involves upgrading, centralizing, automating and routinizing internal cost controls, in effect monetizing the assets that HEIs devote to financial control [34]. Specific areas of focus include procurement, travel-related expense, contract life cycle management, accounts payable, and outsourcing. External financial pressures are forcing HEIs to address internal "spend management" problems, including:

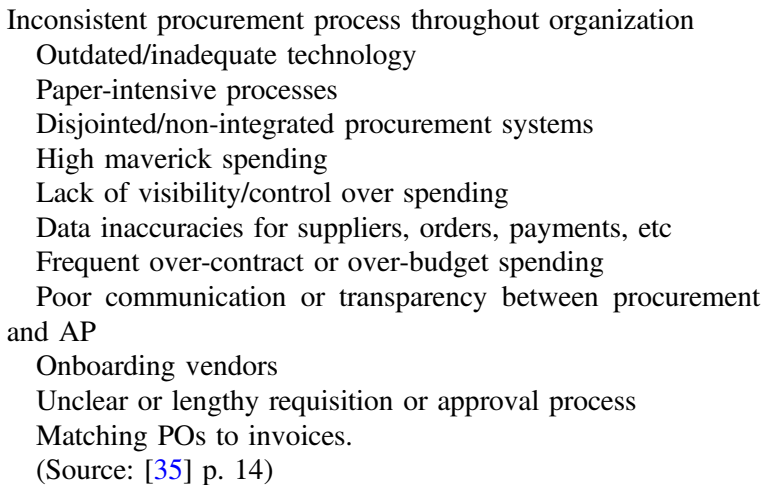

As these problems get addressed, additional resources can be wrung out of HEI operating systems to invest in higher priority assets.

\section{2 "Borrowing" Resources to Invest: Acquiring and Restructuring Debt}

Borrowing resources brings in cash, not unlike wringing out resources (discussed above) and selling monetized assets (discussed later). Several features of debt, however, make it different from other monetization tactics. It brings cash to the table, not by cutting expenses or through increased sales revenue, but by monetizing the credit worthiness of the HEI. When monetization requires substantial near-term resources and promises long-term financial benefits, debt is a potentially viable tactic, especially when the cost of borrowing is low.

Like other monetization tactics, debt has its own set of challenges and potential benefits, and its cost depends in part on existing HEI financial health. Financial health, measured by complex formulas administered by external credit rating agencies, greatly influences the size and terms of the debt that a HEI can reasonably pursue [36]. (The old guideline in lending still applies-"We only lend to organizations that don't need the money.") Debt is both a source of capital as well as a vehicle for managing liquidity.

\subsubsection{Borrowing to Survive Versus Borrowing to Thrive}

Two major financial "bookends" enhance the utility of debt as a source of capital: the overall financial health of the HEI and the value of the assets being invested in with debt-secured resources. HEIs with poor financial health must pay more for the debt they acquire, and HEIs that invest in assets that do not promise enhanced value within a "reasonable" time are not aggressively monetizing those assets. HEIs can find themselves spending increasing amounts of operating capital to service debt that will not simultaneously increase revenues. The experience of Bard College (New York State) illustrates these interactions between debt, credit worthiness, income, and cash flow [37].

First, debt gets expensive when it is relied on to survive, rather than to thrive. In 2016 Moody's Investors Service downgraded Bard's credit rating "edging it farther into junk territory." Moody's justification for the Bard downgrade included declining total cash, increased dependence on lines of credit, and heavy borrowing from its endowment. Its relatively liquid financial assets shrank as it ran up higher debt, increasing the likelihood of a shortage of operating capital. That in turn put more pressure on the college to collect donations to fund its operations. In the words of a Moody's analyst: 
The college is dependent on its endowment and cash flow from borrowing to pay its debt . . . They are not making enough through their core operations to pay their debt service. That's fairly uncommon. [37]

Second, the value of incurring debt is limited to the extent that the resulting newly acquired investment capital does not yield "reasonable" asset monetization or growth. At the time (2016) Bard's debt was going faster than its revenue $(17 \%$ or $\$ 203$ million in debt, vs. $1.6 \%$ or $\$ 190.3$ million in revenues.) Chief among Bard's non-income generating debt obligations was an \$18 million 380-acre estate with historic mansion, financed with a \$13 million mortgage. Although this acquisition may ultimately have been strategically (and financially) wise in the long run, it was not generating any operating revenues in the short run. Was that monetization transaction "reasonable"? A reasonable return on investment is to some extent in the eyes of the beholder. Bard felt it was a wise strategic move, despite its lack of near-term revenue-generating capability. Some HEI financial analysts, however, were more skeptical.

\section{When you talk about buying land, . . . . you need additional capital to turn that into an asset that's actually generating rev- enue .... Just buying the land and holding onto the land is an expense. Turning it into dormitories or something that's going to have a revenue stream, that makes sense as part of a strategic plan. [37] emphasis added}

The ability to incur debt enables some HEIs to undertake and pay for major new initiatives which, without access to debt, would not be feasible. Debt provides access to money and other scarce resources necessary to initiate large scale projects, often as a part of public private partnerships (discussed below).

\subsubsection{Future Look: Making Debt a Part of More Complex Transactions}

Debt remains a means to invest in large projects, to address short term liquidity challenges, and to balance budget shortfalls. Debt for large investments, however, will increasingly get incorporated into more complex financial arrangements with firms that play active roles in asset $o p$ eration as well as finance. In these arrangements HEIs are giving not only a promise to repay a loan; they are often giving over rights to operate assets as well. This involves trading resources to invest.

\section{3 "Trading" Resources to Invest: Joint Ventures and Public Private Partnerships}

"Partnering" covers an overly broad array of HEI relationships today, and travels under a variety of pseudonyms such as collaboratives, co-operatives, shared services, and alliances. The more limited focus here is on those partnerships which are largely financial in form and purpose, especially those which explicitly pull resources from some assets to invest in the development of others through exchanges or trades with other organizations.

\subsubsection{Trading to Enhance HEI Value}

The newest asset monetization transactions are referred to as public-private partnerships, or P3s. A public-private partnership is a long-term agreement between a public entity and a private industry team that is tasked with designing, building, financing, operating, and maintaining a public facility [38]. The past decade has seen a steady increase in the use of P3 structures by HEIs, both public and private. $\mathrm{P} 3 \mathrm{~s}$ range from relatively small partnerships, resembling typical leasing or outsourcing with third parties, to very large, complex arrangements whereby the HEI trades access to its assets to partners who provide financing, managerial and technical expertise on project design and development, and often the right to operate and profit from the asset as well.

Consider first some smaller asset monetization partnerships at one HEI (Virginia Wesleyan University) where modest levels of cost reductions and net revenue generation occurred. As summarized by its president:

\footnotetext{
[We set out to] ... Develop public-private partnerships that increase efficiency and, in many cases, generate revenue. . . . [We] partnered with the area's largest health-care provider for student health services and athletic training. Joint-use facilities can [now] be funded through private dollars from interested, committed parties. .... [We] outsourced the physical plant and endowment management and established a campus conference and catering office that contributes to our 12-month facility [utilization] model. A shared-staff partnership with . . . [another organization] benefits . . . our . . . landscaping priorities. [39] (emphasis added)
}

The difference between "trading" and "selling" is sometimes elusive. Several of Virginia Wesleyans' monetizing transactions appear at first glance to be a series of land and facility leases to other organizations. These arrangements, however, bring in more than "rent" to the monetization initiatives. These partners were "respected nonprofit, like-minded groups [that] bring added prestige and programming to the campus" [39].

Many HEI assets require much more technical expertise than is involved in solely leasing and maintaining buildings, e.g., designing and operating residential complexes, bookstores, and power plants. Monetizing them requires more than an external source of capital, including a wide variety of specialized high-value external expertise. The primary HEI argument against relying solely on internal expertise for monetizing complex HEI assets is straightforward:

A lot of universities are asking themselves, 'Why are we in the business of owning and running our own power plants? That's 
not our bread and butter .... We have some highly qualified folks that work for us internally that manage our assets now, but their job is not to create new things every day. . . . Their job is focused on doing a really good job of maintaining what we have. [40]

HEIs often seek resources to monetize large complex assets through soliciting gifts (capital campaigns, etc.), but assets not associated with an HEI's core mission are not attractive to potential donors. It is particularly difficult to interest donors in funding "underground pipes or the power plant" or parking structures.

One basic form of P3 asset monetization involves HEIs leasing out systems to private companies that will operate them in exchange for significant upfront payment: the HEI trades access to its assets to partners who, for a price, operate them to generate revenue. The HEI then makes regular payments to the partner which invests in the asset, while at the same time the HEI invests its newly acquired cash into academic (core mission) priorities (assets of another type). For example, The Ohio State University entered into a 50 -year contract with an energy company and investment firm to run its utility system. It received $\$ 1.1$ billion at the outset which it invested in academics as well as energy-related research and facilities [40].

\subsubsection{The Role of Incentives in Long Term Trades}

The long-term, high-stakes nature of these contracts necessitates inordinate focus on the incentives built into the contracts. If the HEI is obligated to pay for certain aspects of the arrangement (operations, debt service), the partner needs to be incentivized to guarantee reliability and improve efficiency. P3 projects have resulted in several different types of contracts, all seeking to align the expected costs and benefits of each party with the realities brought about by uncertainties of large-scale risks and multi-year time horizons [40], 41.

Another type of $\mathrm{P} 3$ contracting arrangement, analogous to one used for toll roads, is where the private company recoups its investment in the HEI project by charging user fees. The ability of HEIs to monetize their aging college dormitories is illustrative. To monetize these without partners an HEI would need a lot of available capital and specialized expertise in up-to-date student housing design, development, marketing, and ultimately operation. Wayne State University, instead of self-managing its dorms, sought to lease beds from a third party and off-load some of the associated risk and responsibility for housing students to other firms:

[Wayne State] sought out . . . .partners to demolish an existing 407-bed apartment building and replace it with new and renovated residential space. It went from issuing a request for proposals to obtaining financing in . . . . record time. . . . To expedite construction, the private partner secured bridge financing ....., enabling the project to tap into generally favorable financing for the larger private placement of debt. The university .... locked in favorable financing terms and paid off existing debt, ... [and] moved much of the worry and risk from operations onto the private partner ... includ[ing] design, construction, financing, operations and maintenance of the project over a 40-year life cycle, freeing up university resources to focus on academic and other needs. [38]

Historically P3s have been particularly useful to HEIs in the non-academic core areas, including physical infrastructure, areas requiring a deep bench of expertise, large investments of capital, long-time frames, and potentially large risks. One of the largest US examples to date is the Merced campus of the University of California, covering some 219 acres and almost two million square feet of new facilities. The $\$ 1.2$ billion project includes classrooms, offices, research facilities, residences, and utilities [38]. It employs an "availability" method of payment whereby the university compensates a firm directly according to a predetermined formula and schedule for postconstruction operations and maintenance of the facilities over a 39-year life cycle, plus 50/50 splits among partners for any future monetary gains resulting from refinancing and or cost-saving measures introduced by the developer.

Trading resources through $\mathrm{P} 3 \mathrm{~s}$, as with other asset monetizing tactics, can serve differing purposes. Those HEIs with few financial challenges tend to pursue partnerships as opportunities, including developing a "strong niche" through differentiation or enhancing size and operating margins. On the other hand, those with many financial challenges tend to seek survival through partnerships as a new strategy or survival through efficiency [42, p. 4].

\subsubsection{Future Look: Moving Toward Core Academic Assets}

Historically P3 arrangements to upgrade core academic assets had been avoided in part due to faculty resistance and in part due to in-house faculty expertise which has been sufficient to upgrade these academic assets. Going forward, however, these academic assets are being considered as P3 possibilities due to growing expertise required to upgrade them (e.g., online platforms, learning management systems, and instructional performance analytics) and the changes in faculty hiring practices, e.g., from (broadly skilled) "professor" to (narrowly skilled) "instructor" [42].

\section{4 "Soliciting" Resources to Invest: Gifts, Grants, Endowments}

A fourth tactic for HEI asset monetization entails asking for resources (gifts and grants), usually through advancement offices, affiliated university foundations, and departments of contracts and grants. Unlike "wringing out" and 
"borrowing", "soliciting" entails a close connection between investable resources and specific assets being monetized. Third parties are being asked to provide the resources to invest in targeted, pre-identified assets, be they buildings, research projects, academic programs, faculty positions, or student scholarships. These "giver-gift-asset" connections exist regardless of whether the gift ends up in the HEI's operating budget or in its endowment.

\subsubsection{The Cost of "Free Money"}

Among HEIs that solicit resources, the publicity surrounding very large gifts creates the impression of great revenue opportunity for HEIs, all "for the asking". This is true for some HEIs, but not so much for most. Of the US \$4.7 trillion spent on all education worldwide recently, donors' contributions accounted for just $0.3 \%$ of total spending, which is barely visible in absolute amounts [43]. Higher education's share of the $\$ 4.7$ trillion is only about $\$ 1.9$ trillion [44]. In the U.S. recently (2018), 3700 HEIs surveyed raised a total of $\$ 46.73$ billion in gifts, or an average of $\$ 1.26$ million per HEI. Some do vastly better than others. Twenty HEIs, less than $1 \%$, captured $28 \%$ of that total amount, and they were not all previously well-endowed private universities [45].

The most widely recognized HEI solicitation tactic is a widely publicized, multi-year "campaign", complete with aspirational goals, announcements of major gifts, and descriptions of the assets that benefit from these gifts, such as endowed faculty positions, buildings, and research programs. Less well advertised are the costs required to secure these gifts. Gift solicitation is compelling in part because it requires few resources relative to the dollars raised [46]. Furthermore, revenues from donations can increase the amount of discretionary dollars available to institutional leaders. Even though only a small share of gifts is technically unrestricted, many restricted gifts are "effectively unrestricted", i.e., restricted to activities that the institutions would perform anyway, or at least be willing to perform if funded externally.

Solicitation works only when the assets which HEI leaders want to monetize are the same as those which donors want to support; individual gifts are usually targeted in response to donors' wishes. For example, most of gifts from UCLA's 2014, \$5.5 billion multi-year campaign were directed by donors to support student scholarships, endowed faculty positions, research projects, and building needs, all associated with its "core mission" [47]. HEIs that solicit private resources also seek to continue to secure as much traditional government support as possible. As UCLA's Chancellor argues:

The vast majority of donations are restricted to donor desires and cannot be used for ongoing operational expenses. . . People don't generally donate to keep the lights on or keep the physical plant in good shape ... Philanthropy is not a substitution for state support. (quoted in [47])

Ironically, HEIs that receive more governmental appropriations are more, not less, successful in raising private gifts from other sources [48]. Donors are often more inclined to make gifts to well-off HEIs rather than to HEIs that desperately "need" the gift; and increased state support adds to the "well-off" perception, especially if it helps the HEI to increase benefits available to donors.

UCLA's $\$ 5+$ billion in gifts monetized many assets over the years, but the cost to secure them has been substantial. To raise each dollar of gift, how much will/can/should each HEI spend-30 cents? 50 cents? 70 cents? On route to securing \$5+ billion, UCLA had to secure contributions from more than 220,000 donors from all 50 states and 99 countries. This required the work of more than 400 fundraising officials on UCLA's payroll plus 1500 unpaid but university-supported volunteers, a sizeable commitment, and UCLA's staffing for solicitation was not uniquely high for its size [47].

The salaries and benefits of advancement staff are only the most direct of costs associated with HEI solicitations; additional indirect costs include facilities usage, travel-related and entertainment-related expenses, food service, information technology support and accounting. The number of cents an HEI spends to raise a gift of $\$ 1.00$ is not easily calculated, let alone publicized. On top of these costs of raising and securing the gift are the costs associated with administering the operational, financial, and legal conditions associated with each gift. Both the total costs and often the total benefits of gifts tend to be underreported, but, either way, it is difficult to estimate whether UCLA would have been better off pulling resources from its advancement initiative or investing additional resources.

\subsubsection{Potential Donors as HEI Assets}

HEIs do not "own or control" potential donors, but HEIs do possess a modicum of potential donor goodwill, inspired either by what HEIs do or what they are. Potential donors are, therefore, HEI assets, but it is difficult to estimate individual donor giving proclivities prior to asking. How much are HEIs willing to invest up-front and on-going in both money and time in the hopes of raising future dollars from some people they have not even met yet? Like most HEI gift campaigns, UCLA pursued and secured a small number of very large gifts and many smaller ones. Gifts ranged from $\$ 1$ to $\$ 100$ million, but $81 \%$ of the gifts were under $\$ 1000$. The donor of a large gift is a usually a donor who has already made one or more smaller gifts, so all small gifts create a pool of people who are candidates for larger gifts. Not surprisingly, "periodic" capital campaigns now virtually perpetual. 
The most obvious target populations for giving are students - past, present, future-and their families. Yet, all students/alums are not equally likely givers. Likely givers to HEIs are those who "do so as a part of an overall pattern of prosocial behaviors to improve society... behaviors and dispositions... formed early in life and are nurtured before, during, and after college" [49, p. 3]. HEI leaders, then, potentially boost giving participation among alumni if they engage them as partners in tackling key societal problems that mirror their own civic and philanthropic interests.

\subsubsection{Gifts to Endowments Versus Current Operations}

Endowments represent the treatment of a gift, locking up capital from which only earnings can be spent annually. Apart from fulfilling stated philanthropic goals, endowments serve as a hedge against future uncertainty and help fulfill aspirations of HEI immortality. They also appeal to prospective benefactors in its durability [50], "donor immortality" of a sort. The benefits of permanence (keeping the gift intact and spending only earnings annually) are compelling, but also work against the benefits of putting all the money to good use immediately. All else equal, donor preferences lean toward endowments, while HEI preferences lean toward operating funds.

In return for large gifts, HEIs often promise naming opportunities, i.e., placing the donor's name on a building, program, etc., plus other benefits such as tickets to events and access to research, athletic, and artistic venues. HEI naming practices include, in addition to donors, famous people whose name itself creates positive feelings toward that HEI. "Value" to an HEI can be more than "cash" and can include something as nebulous as enhancing the HEI's brand. Naming some HEI asset after a famous person has the same risk as naming it after a donor, i.e., that in the future the reputations of either could be reevaluated and downgraded as history gets reinterpreted.

\subsubsection{Future Look: New Competitors, New Business Models, Old Uses}

If the primary role of trustees is to sustain the mission of the institution in perpetuity, they must be concerned with all expenses and all sources of income, not just those associated with endowments. Recently, spending and fees at colleges and universities have been rising faster than family incomes. If this trend persists, increasing emphasis will be placed on endowments as a source of operating income [51].

University alum and donor markets are increasingly national and global, and HEIs are competing for gifts with other philanthropies, including other HEIs. This requires that HEIs somehow expand the number and yield of donors without increasing unit costs. This pressure is encouraging pursuit of donors, not so much with more expensive personal visits around the world but with increased use of social media for relationship building [52]. HEIs will continue to globalize their solicitation capacity, not just because of financial returns but also due its contribution to brand awareness and reputation building.

\section{5 "Selling" Monetized Assets: Course, Degrees, Research}

The central asset monetization tactic of HEIs is selling the services they have created, e.g., courses, programs, degrees, consulting, and research, all of which are produced through the deployment of its primary assets, e.g., people (in all kinds of roles), buildings, libraries, and technical infrastructure. Although "selling" is a part of all monetization transactions, that term is used here in a more limited sense, i.e., where prices are publicly posted, and there are many potential customers. Academic programs (courses, certificates, degrees) constitute by far the largest source of revenue for most HEIs (along with patient fees at HEIs offering patient care services).

\subsubsection{Limits to Selling Mainstream Services}

Many public HEIs, like their private counterparts, are becoming increasingly reliant on tuition charges relative to government appropriations. FY 2017 marks the first time in U.S. history, for example, that more than half of all states relied more heavily on tuition dollars than on government appropriations to fund their public higher education systems [53]. Globally households are picking up on average about one fifth of the bill for education, a share which rises to almost $50 \%$ in less well-off countries. This share currently ranges from a high of $63 \%$ of total education spending in the poorest countries to a low of $1 \%$ in the richest [43].

Most HEIs believe they are near the upper limit of their tuition price setting capacity. Raise fees too little and the added revenue from higher prices is not captured; raise fees too steeply and demand falls, losing potential revenue from fewer sales. (The time has passed when a HEI's price was seen as a proxy for its inherent value.)

Different services yield different margins (the difference between a HEI's cost to produce and its selling price). HEIs with large enrollments have the advantage of spreading their fixed costs over more students. Regardless of volume, however, the margins of different services are rarely known or considered, even to the point of not knowing whether a positive margin exists. Consider, for example, tuition charges for courses and majors. Different courses and different majors require differing levels of resources to produce, even though the prices charged are largely the same; the margins can vary significantly.

HEIs are more discerning, however, when it comes to pricing degrees. They seek to maximize top line income 
through price discrimination, charging different prices for the same degree, thereby capturing the "consumer surplus" of well-off families but also discounting tuition, sometimes deeply, for families of low-income students. Those discounts drive down the average tuition price, and HEIs that use extensive discounting (somewhere in excess of about $13 \%$ of tuition revenues), top-line revenue may not fully cover the cost of degree production [54]. Well-endowed HEIs can cover these losses, but not many poorly endowed HEIs can.

\subsubsection{After Selling, Collecting}

A sale is only as good as the revenue it generates, and the costs associated attempting to collect outstanding debts can be time and resource consuming, unprofitable, and reputation tarnishing. HEIs are reluctant to exert inordinate pressure on financially struggling students and their families. Receivables, however, can be monetized by selling them to agencies which specialize in collecting on past due accounts. As advertised by one such firm:

\footnotetext{
Our team of [accounts receivable] professionals excels in monetizing assets immediately very often using our own capital. This means we can quickly purchase your delinquent signature loan portfolios as well as NSF [not sufficient funds] checks, installment agreements, emergency loans and tuition in order to help you improve [the accounts receivable portion of] your balance sheet. [55]
}

As is the case with so many potential monetization decisions, without credible estimates of cost savings or revenue enhancement from monetizing accounts receivable, HEIs are inclined to continue their current collection systems even though outsourcing them may free up resources.

\subsubsection{Capturing the Market Value of Faculty Research}

Selling faculty research is different from selling faculty teaching in part because of the differences in value that faculty research generates. Unlike faculty teaching, faculty research at most HEIs is difficult to value and to monetize, and it is treated only as an indirect contributor to overall reputation.

The research of some faculty is being monetized. For purposes of analysis, partition faculty and their research into three groups: (1) most faculty, (2) grant-getting faculty (a small subset), and (3) faculty who can monetize their intellectual property (IP) (an even smaller subset). Most faculty, including those that produce publications from their research, are usually credited with any resulting income, not their HEIs. This is largely because there is little economic value directly traceable to the publications, except reputational value to the author. Grant-getting faculty contribute a portion of their grant funds to the incremental costs associated with HEI fund administration and, indirectly, contribute to the HEI scholarly reputation. IP-generating faculty members, producers of research worth protecting by patents or licenses, pay overhead to their HEI like other grant-getting faculty, but in addition split any income from the sale of research three ways-between themselves, their academic departments, and the central administration of the HEI.

Revenue-generating faculty research comes from a very small fraction of total faculty, even at research intensive HEIs. These high-value IP faculty "assets" require sizeable investments of resources to recruit and to support. At the same time, these few faculty generate a sizeable return on the HEI's investment in them-in money, in prestige, and in future donors. The spillover effects of these returns on HEI drawing power for students and faculty can be great, but for most of what is considered faculty research, institutional impacts are ambiguous. In contrast to selling various forms of instructional services, monetizing faculty research requires a substantial commitment of resources just to participate, and potential returns, other than reputational, are unclear.

\subsubsection{Future Look: Micro-analytics for Pricing Macro-services}

Because expenditures and revenues from producing and selling faculty services is a large fraction of HEI budgets, initiatives to monetize them will continue, but with increasingly finer-grained analytics to better understand the margins (both positive and negative) of individual courses, programs, degrees, and even research. These are the parts of the HEI house that have not been routinely examined financially.

Historically HEIs charge the same sticker prices across differing courses and degrees, but then vary that price through various forms of student aid with no consideration given to the courses or majors that individual students are taking. In fact, margins vary significantly across courses and programs, even if they are not priced accordingly. Uniform course and degree pricing significantly reduces the fraction of tuition revenue that can be applied to HEI fixed costs. (One crude analogy would be using the differentiated pricing scheme of selling airline seats and then randomly assigning passengers to any seat on any plane going to the same destination.) This practice, plus mounting pressure to increase enrollments, severely limits the margins that HEIs can earn from student tuition. This legacy pricing problem is being addressed by differentiated tuition pricing of courses and degrees based more on (1) market demand and (2) public (HEI and state) priorities [56, p. 323].

The highest margins are associated with programs that are (1) least expensive to produce and/or (2) serve students whose effective tuition price is the highest. As HEIs seek to monetize programs and courses, they will have to consider combining the effects of targeted tuition subsidies, 
differential program pricing, and decentralized budgeting. With flexible tuition and targeted subsidies, students with a high willingness to pay and those choosing low-cost programs will contribute more toward shared fixed costs, and there will be less inefficiency. Several HEIs already have several years of experience with differential tuition pricing [56, p. 325].

\section{6 "Creating” Monetized Assets: New Businesses, Programs, Services}

All services and goods that HEIs sell, trade, solicit money for, or borrow money on had to be first created and at some cost. Creating monetized assets requires basic innovation; pulling resources from some assets to apply to the creation of other assets - creating, enhancing, and growing them as innovations. Most innovations are what Clayton Christensen called "sustaining innovations", i.e., those which improve upon the services that HEIs already offer, but don't "disrupt" the firm or the industry [57]. Each HEI innovation has two properties: (1) it is new, meaning there is something about it that is different than what has come before; and (2) it creates value, meaning that it has some sort of practical benefit or impact (as distinct from "pure creativity" which may not have any practical benefit) [58].

\subsubsection{Innovations Big and Small, Core and Non-core, Easy and Difficult}

Innovations can be big and dramatic, e.g., Purdue's incorporation of Kaplan add a law school and a large-scale distance teaching capability in one transaction [59], or they can be focused and incremental, e.g., adding a micro-biology major within the biology department. Courses, programs, majors, and degree requirements are routinely created, upgraded, or otherwise changed, as are student services, teaching methods, inter-institutional articulation initiatives, and, well, all asset monetization initiatives described in this chapter. Type cast as tradition bound, many HEIs pursue more innovations than they are given credit for, innovation defined here as "the implementation of new initiatives in order to drive growth, increase revenue, reduce cost, differentiate experience, or adjust the value proposition" [60].

This last monetization tactic-creation of new businesses, programs, and services and, thus, assets-represents in effect the flip side of the first tactic-reductions and cuts from existing assets. One emphasizes productivity enhancement (reducing costs relative to benefits gained) and the other emphasizes creating and marketing new initiatives. Together they reflect a broad incremental shift in investments from some legacy assets toward the creation and enhancement of emerging assets. If the subtext of traditional budgeting is maintaining prior resource commitments, then the subtext of monetization is shifting prior resource commitments.

\subsubsection{The Special Case of Monetizing Faculty Research}

Seeking to monetize faculty research beyond current levels presents a special challenge; only HEIs with already substantial research capability and infrastructure are likely to entertain further monetization. Although research constitutes a critical leg of the historical three-legged HEI stool of teaching, research, and service, comparatively few HEIs have developed the capacity to commercialize their research (intellectual property) through licensing, patents, and joint-venturing, and start-up businesses. ("Technology transfer" is examined much more thoroughly in Chap. 5 of this book.) The high barriers to entry and profitable participation in this monetizing tactic require: a critical mass of highly trained faculty engaged in potentially market-relevant research and development, a technically qualified office of "technology transfer" staff tasked with harvesting and selling faculty IP, the requisite facility infrastructure (labs), an ample supply of highly capable graduate students, and an ideal location in a region with concentrations of relevant firms (potential partners), all globally networked to relevant entrepreneurs and technical experts.

The vast majority of HEIs are not "research intensive", or more accurately, do not produce sufficient quantities of market-relevant research to warrant the intensive investment in those assets necessary to monetize with faculty research. This is not to say that the perception of faculty expertise, as reflected in their research, is not important in teachingoriented HEIs. Rather, "research" there translates into broad, entrepreneurially-oriented initiatives, separate and apart from licensing and selling intellectual property. They include activities, characterized by Abreu [61] as "problem-solving activities" including consultancy, contract research and joint research with external organizations; participation in research consortia, providing informal advice, prototyping and testing for external organizations, hosting personnel from external organizations and taking temporary leaves-of-absence to work in those organizations. (Research-oriented HEIs do more of these as well.) Monetizing the research of faculty in teaching-oriented HEIs requires much less incremental HEI investment, and the potential gains are, correspondingly, less.

Among for-profit HEIs, the value of faculty research expertise is marginal compared to the value of faculty experiential, vocational, professional, and instructional expertise. Other HEIs are inching toward this for-profit model as they replace tenure track faculty positions with fixed-term contract instructors (sometimes referred to as "clinical" faculty). These innovations incrementally shift faculty resources from research expertise to teaching 
expertise, creating in effect, a different business model, pursuing different markets, with different cost structures. For example, while the research university professor designs her class, teaches it, and then tests the students for comprehension, these three tasks are often performed by three separate individuals in for-profit HEIs [62]. Instruction has been separated from the research and service components, thus significantly reducing its cost, while focusing more on customer service and convenience and less on historical notions of faculty roles.

Another innovative feature of for-profit HEIs involves a narrowing of the traditional undergraduate curriculum found in so many HEIs. They are investing primarily in small numbers of career-relevant, low-cost, high demand instructional programs and avoiding the majority of majors found among HEIs in the other two sectors. To achieve this, for-profit HEIs aggressively excise programs that are in low demand, due either to regional or overall obsolescence ("wringing them out") [63].

At the time of this writing, most HEIs are seeking to monetize their online teaching (and many other) assets in response to COVID-19, creating new modalities for existing programs, inventing new laboratory experiences for science courses, and, more generally, seeking to reorganize campus life to accommodate external health-related risks and mandates. The tragedy of the pandemic illustrates the "two-sided" nature of asset monetization, i.e., that HEIs are responding to this external threat only to the extent that they can secure sufficient resources needed to invest in innovations. Unfortunately, the same pandemic that is requiring major (costly) innovations is also simultaneously causing serious shortfalls across most major revenue sources. HEIs are thus securing resources through most, if not all five, of the other monetization tactics to cope with it: wringing out, borrowing, soliciting, trading, and selling.

Innovations are constrained not only by a lack of freed up resources, but also by inherent preferences for more of the same (not "too innovative"). The pursuit of reputational "excellence" fosters homogenization, which in turn reinforces the status quo [64]. Accreditation policies and government regulations also retard internal HEI change processes. Research suggests that most organizational change in any sector originates not from internal pressure, but from external pressure, and HEIs are no exception [64, p. 11]. The HEI creation or innovation problem is not getting new ideas and adopting them; it is challenging old practices with new conceptions and getting rid of the old practices.

\subsubsection{Future Look: Monetizing Innovation to Include Faculty}

Monetization initiatives are expanding more into instructionally related assets, e.g., cutting out or restructuring old programs, courses, and course formats and replacing them with new, more cost effective, offerings and instructional modalities [65]. Monetization here has been difficult due to existing faculty prerogatives (they govern curriculum) and incentives (a lack thereof). With increased financial pressures plus recent developments in data analytics [66] and responsibility-centered management [67], instruction and other academic work will increasingly be subject to the scrutiny of monetization.

Specific questions about course and program redesign include:

- How much will it cost to adopt a new instructional model for an existing course, such as active learning in an introductory science class, or to add a new course such as a senior seminar to an existing curriculum? What changes to existing offerings and formats would be needed to free up enough resources to make such an adoption revenue neutral?

- If we want to increase enrollment in a relatively expensive major (i.e., one that requires subsidy), how much do we need to increase enrollment in a relatively inexpensive one (e.g., one that produces a surplus) to keep the budget in balance?

- If we need to boost overall enrollment, what are the options for increasing offerings within the increased tuition that will be generated? [65], p. 3].

Applying monetization to courses and programs differs from simpler cost reduction tactics (wringing out resources), which asks "What resources can I free up to invest?" Instead, it asks a more complex question, "[Can we] gather and use information about [instructional] costs that allows us to maximize the quality we get for any level of spending" [65, p. 3]?

\subsection{Conclusion and Discussion: Process Versus Purpose in a New Environment}

Survival and growth are eclipsing maintenance in higher education. As increasingly intense financial pressures are revealing, HEIs require more assets to be monetized, more places from which to draw resources, and more places to advantageously invest those resources. That "bad news" of financial pressure is also the "good news" of focused attention. Balanced annual budgets are no longer a sufficient goal; heightened aspirations for margins and growth combine with significant revenue shortfalls to become the perfect storm of a "new normal".

Asset monetization is a process for pursuing this new normal. It provides the means to pursue net income annually and net asset growth continuously. No single monetization tactic, including that of creation/innovation, can serve as the 
"silver bullet" to solve HEI financial challenges. Changes in markets are now happening too rapidly, and the scale of required responses is too large to rely solely on the very small (often non-existent) discretionary resources that show up in traditional budgeting processes.

Today's HEI leader is compelled to (1) assess the full array of HEI assets, (2) identify investments that are most likely to return the most net income and (over time) growth in net assets, (3) determine which resources can be marshalled from where, with the least loss in overall HEI value, (4) fund those investments, and still (5) maintain HEI stability and continuity. HEI work is a recurring process of acquiring resources and putting them to work- not a new view in that money-related concerns have existed as long as higher education itself has existed [68].

What is different is an increased emphasis on the immediacy and scale of HEI responsiveness, demanding increased interdependency between the academic and business sides of each HEI. Increasingly sophisticated financial practices and analytics will enhance, not diminish, the pursuit of HEI academic purposes. Short-term (annual) financial performance is intimately tied to long run net asset growth, both in the service of pursuing HEI purpose. Achieving net revenues and net asset growth is not achieving HEI purpose, but achieving HEI purpose cannot exist without net revenues or net asset growth.

HEI's six monetization tactics require widely shared, intimate, and simultaneous knowledge of financial means and institutional ends and a governance structure which is responsive and responsible across them. Decisions to pull resources from some assets and invest in others should not be made without intimate knowledge of the implications of both the academic and business dimensions. All forms of monetization require assumptions about the value of where resources come from and where they are applied, across all organizational units.

Historically, HEIs have divided academic and business functions, starting at the top. Today, the division is being erased. All HEI expenditures are increasingly quite sensitive to changes in revenue patterns based on changes in demand for what is sold [69] and the cost of inputs to produce what is sold [24]. For these reasons alone, HEI governance structures will continue to evolve toward increased alignment between authority and responsibility for monetizing assets closer to the differentiated markets that HEIs pursue.

Neither promising tactics nor slavish adherence to a particular strategic vision will ensure the long run success, even survival, of an HEI. What will foster, indeed define, success will be the long run growth in net assets, especially relative to "peer" (competitor) HEIs. The questions are straightforward. By what percent (and by what amounts) have the net assets of my HEI grown over the previous twenty years? How does this percentage compare with the performance of those HEIs with which we compare ourselves? Based on these numbers, do we consider ourselves successful?

\section{References}

1. A. Donetti, Stop considering people as assets,LinkedIn, 13 May 2016. [Online]. Available: https://www.linkedin.com/pulse/stopconsidering-people-assets-alessandro-donetti/. Accessed 2 June 2020

2. L.J. Noe, J.A. Geerts, G.L. Frank, Managing People as Assets, Des Moines (Millennium HRM Press, IA, 2012)

3. R. Azziz, G. Hentschke, L. Jacobs, B. Jacobs, Strategic Mergers in Higher Education, Baltimore (Johns Hopkins University Press, MD, 2019)

4. M. Korn, B. Douglas, J. Chung,Coronavirus pushes colleges to the breaking point, forcing "hard choices' about education. Wall Street J (2020)

5. M.Z.I. Al-Khathlan, A proposal to achieve financial independence in Prince Sattam Bin Abdulaziz University in Accordance with the New System of Universities and Vision 2030. Int J Higher Educ 9 (3), 15-27 (2020)

6. PwC Middle East, Saudi Arabia passes new Universities Bylaw, December 2019. [Online]. Available: https://www.pwc.com/m1/ en/services/tax/me-tax-legal-news/2019/saudi-arabia-passes-newuniversities-bylaw.html\#: :text=In\%20brief,gazette $\% 2 \mathrm{C} \% 20$ the \%20\%E2\%80\%9CBylaw\%E2\%80\%9D. Accessed 1 Sept 2020

7. R. Azziz, G. Hentschke, B. Jacobs, L. Jacobs,Mergers in higher education: a proactive strategy to a better future (TIAA Institute, 2017)

8. L.K. Chen, Transformation 101: how universities can overcome financial headwinds to focus on their mission (McKinsey \& Co., 2019)

9. C. Morrill,Guide to Analyzing University \& College Financial Statements, Canadian Association of University Teachers (2016), Available: https://www.caut.ca/sites/default/files/caut-guideanalyzing-university - college-financial-statements.pdf

10. D. Doyle, B. Ladd,Developing a Balance Sheet, Oklahoma State University Extension (2017)

11. University of Oxford, Financial Statements 2017/2018 (2018), https://www.ox.ac.uk/sites/files/oxford/field/field_document/University $\% 20$ of $\% 20$ Oxford $\% 2 \mathrm{C} \% 20$ Financial $\% 20$ Statements $\% 202$ 017-2018.pdf

12. Northwestern University, Northwestern University 2001 Financial Report (Northwestern University, Evanston, IL, 2002), https:// www.northwestern.edu/financial-operations/annual-financialreports/2001-Financial-Report.pdf

13. Northwestern University, Northwestern University Annual Report 2019 (Northwestern University, Evanston, IL, 2019), https://www. northwestern.edu/financial-operations/annual-financial-reports/

14. A. Barone, "Asset," Investopedia (2020). [Online]. Available: https://www.investopedia.com/terms/a/asset.asp. Accessed $2 \mathrm{Feb}$ 2020

15. Your Dictionary, "Examples of Assets," Your Dictionary (2020). [Online]. Available: https://examples.yourdictionary.com/ examples-of-assets.html. Accessed 2020

16. Austen Group, "Financial Indicators Tool (FIT): Dominican University," (2016). [Online]. Available: https://www.dom.edu/ sites/default/files/pdfs/about/OIE/About_OIE_dominican_university_ 2016_148496_fit.pdf 
17. J. Evans, "Asset monetizing:" in-ground \& above-ground asset monetization," Nalten Commodities \& Resources (2018). Available: https://www.nalten.com/post/asset-monetizing

18. D. Coombs, What is monetization? January 2016. [Online]. Available: https://www.youtube.com/watch?v=84Ts9lVZ4b4

19. Merriam-Webster, Financial definition of monetize, 2 February 2020. [Online]. Available: Merriam-Webster, Financial Definition of Mone, https://www.merriam-webster.com/dictionary/monetized\#: :text=In $\% 20$ economic\%20terms\%2C\%20monetize\%20means,or\%20some thing $\% 20$ with $\% 20$ transferable $\% 20$ value.\&text=The $\% 20$ process $\% 20 \mathrm{o}$

20. A. Ganti,Monetize: what does monetize mean? Investopedia (2019)

21. Hannover Research, Financial reporting in higher education, Hannover Research (2014). Available: https://www.investopedia. com $/$ terms $/ \mathrm{m} /$ monetize.asp\#: :text=Monetize $\% 20$ refers $\% 20$ to $\%$ 20the $\% 20$ process,or\%20object $\% 20$ into $\% 20$ legal $\% 20$ tender

22. A. Usher,The politicization of university accounting, Higher Education Strategy Associates (2017). Available: https://www. hanoverresearch.com/media/Financial-Reporting-in-Higher-Educa tion.pdf

23. Institute for Education Sciences, "Post-Secondary Education Revenues," National Center for Education Statistics (2020). [Online]. Available: https://nces.ed.gov/programs/coe/indicator_ cud.asp. Accessed 10 April 2020

24. R.G. Ehrenberg, American higher education in transition. J. Econ. Perspect. 26(1) (Winter 2012), 193-216

25. M.K. Townsley, Financial Strategy for Higher Education: A Field Guide for Presidents, CFOs, and Boards of Trustees, Lexington (Lulu Publishing Services, KY, 2014)

26. W.H. Schacht, The Bayh-Dole act: selected issues in patent policy and the commercialization of technology,Congressional Research Service (2012). Available: https://fas.org/sgp/crs/misc/RL32076.pdf

27. AUTM, Who we are, AUTM (2020). [Online]. Available: https:// autm.net/about-autm/who-we-are. Accessed 14 May 2020

28. R.J. Shiller, Irrational Exuberance, 2nd edn. (Random House Inc., New York, 2005)

29. M. Kich,Closing a University Golf Course: monetizing institutional assets, Academa Blog (2017). Available: https:// academeblog.org/2017/01/19/closing-a-university-gold-coursemonetizing-institutional-assets/

30. N. Smelser,Contemporary trends: diagnosis and conditional predictions, in Dynamics of the Contemporary University: Growth, Accretion, and Conflict (Berkeley, CA, University of California Press, 2013), pp. 78-116. Available: www.jstor.org/stabl

31. Penn State News, Barron discusses cost-savings, shares strategies for new efforts, Pennsylvania State University, 15 September 2017. [Online]. Available: Penn State News, (September 15, 2017), Barron discusses cost-savings, shares strategies for new efforts, accessed 6/17/2020 from: https://news.psu.edu/story/ 482813/2017/09/15/administration/barron-discusses-cost-savingsshares-strategies-new-efforts. Accessed 17 June 2020

32. E.J. Barron, Strategies for addressing budget challenges: President's report to the board of trustees (2017). Available: https:// news.psu.edu/story/482813/2017/09/15/administration/barrondiscusses-cost-savings-shares

33. National Association of Independent Colleges and Universities, Controlling Costs, National Association of Independent Colleges and Universities (2016). [Online]. Available: National Association of Independent Colleges and Universities, https://www.naicu.edu/ research-resources/research-projects/controlling-costs. Accessed 15 Mar 2020

34. D. Smith, The Strategic Spend Management Imperative in Higher Education (Huron Consulting Group, 2020). Available: https:// www.huronconsultinggroup.com/insights/strategic-spend-mana gement-imperative
35. A. Barnett, Major Bottoms Jr., J. Kim,2019 Procurement Insight Report (Coupa, 2019). Available: https://www.coupa.com/

36. Moody's Investors Service, Rating Symbols and Definitions, Moody's Investors Service, January 2020. [Online]. Available: Moody's Investors Service, (January, 2020), Rating Symbols and Definitions, accessed 4/15/2020 from: https://www.moodys.com/ sites/products/AboutMoodysRatingsAttachments/MoodysRating SymbolsandDefinitions.pdf

37. R. Seltzer,Bard's Big Cash Crunch, Inside Higher Ed, 24 August 2016. [Online]. Available: Seltzer, Rick, (August 24, 2016), Bard's Big Cash Crunch, https://www.insidehighered.com/news/ 2016/08/24/bard-college-faces-liquidity-and-strategy-questions. Accessed 5 May 2020

38. C. Charles, A Few Lessons About Public-Private Partnerships, Inside Higher Ed, 28 January 2019. [Online]. Available: Renner, Charles, (28 Jan 2019), https://www.insidehighered.com/views/ 2019/01/28/advice-institutions-embarking-public-private-partner ships-opinion. Accessed 10 Apr 2020

39. S.D. Miller, Position for Strength, Business Officer, July-August 2019. Available: https://businessofficermagazine.org/features/ position-for-strength/

40. H. Busta, Colleges look to public-private partnerships for help with sustainability (Education Dive, 2020). [Online]. Available: Busta, Hallie, (11 October 2019), Colleges look to public-private partnerships for help with sustainability, Education, https://www. educationdive.com/news/plugging-in-colleges-seek-partners-tohelp-reach-energy-goals/564868

41. E.Y. Parthenon, Public-private partnerships in higher education: what is right for your institution? (2017). Available: https://cdn.ey. com/echannel/parthenon/pdf/perspectives/EY-Parthenon-P3sbusiness-of-Highered.pdf

42. E.Y. Parthenon, Strength in numbers: strategies for collaborating in a new era for higher education (2016). Available: https://www. ey.com/Publication/vwLUAssets/EY_-_Strength_in_numbers:_ Higher_education_collaboration_report $\$$ Fi

43. Global Education Monitoring Report Team, Global education monitoring report, 2019: Migration, displacement and education: building bridges, not walls (UNESCO, 2018). Available: https:// unesdoc.unesco.org/ark:/48223/pf0000265866

44. J. Kim, The \$1.9 Trillion Global Higher Ed Market, Inside Higher Ed, 2 May 2017. [Online]. Available: https://www.insidehighered. com/blogs/technology-and-learning/19-trillion-global-higher-edmarket

45. K. Bryan, 20 colleges raised 28\% of all funds in 2018: 3 reasons why \& 4 strategies to address this challenge (Digital Media Solutions, 2019). Available: https://insights.digitalmediasolutions. com/articles/higher-education-fundraising-20

46. P.M. Rooney, A better method for analyzing the costs and benefits of fundraising at universities. Nonprofit Manage. Leadership 10(1) (1999). Available: https://core.ac.uk/download/pdf/46959739.pdf

47. T. Watanabe, With $\$ 5.49$ billion haul, UCLA rivals private colleges in fundraising - it's part of a trend, inLos Angeles Times, 26 February 2020. Available: https://www.latimes.com/california/ story/2020-02-26/ucla-fundraising-billion-private-philan

48. J.J. Cheslock, M. Gianneschi, Replacing state appropriations with alternative revenue sources: the case of voluntary support. J. Higher Educ. 208-229, (2008)

49. D.J. Weerts, Alumni giving as civic expression. Philanthropy Educ 2(1), 1-24 (2018)

50. H. Jones, The English civic universities: endowments and the commemoration of benefactors, in Dethroning Historical Reputations: Universities, Museums and the Commemoration of Benefactors, London (University of London, 2018)

51. R.T. Kaufman, G. Woglom,Managing private college finances in an environment in which spending and revenues grow at different 
rates. J. Educ. Fin. 34(2):196-211 (2008). Available: www.jstor. org/stable/40704353

52. K. Hannon, Rethink your advancement budget to raise more. It's that simple,Raise Hub, 7 April 2015. [Online]. Available: https://www. evertrue.com/2015/04/07/rethink-advancement-budget-raise-more/

53. A. Carlson, SHEEO releases state higher education finance FY 2017,State Higher Education Executive Officers Association, 29 March 2018. [Online]. Available: https://sheeo.org/sheeo-releasesstate-higher-education-finance-fy-2017/

54. N.W. Hillman, W. Nicholas, Tuition discounting for revenue management. Res. Higher Educ. 53(3), 263-281 (2012). Available: https://www.jstor.org/stable/41475391?seq=1

55. Hilco, Hilco Receivables (2020). [Online]. Available: https:// www.hilcoreceivables.com/education-solutions. Accessed 7 May 2020

56. G. Fethke, Decentralized university budgeting, united with a more flexible tuition structure. J. Educ. Fin. 39(4), 323-343 (2014)

57. Christensen Institute, Disruptive Innovation (Christensen Institute, 2020). [Online]. Available: https://www.christenseninstitute.org/ disruptive-innovations/

58. D.S. Duncan, A. Trotter, B. Kummerli, Why your company needs a common innovation language: the first step in bringing clarity to your innovation efforts, Innosight, April 2020. [Online]. Available: https://www.innosight.com/insight/why-your-company-needs-acommon-innovation-language $/$ ?utm_source=adwd\&utm_medium $=$ paidsearch\&utm_campaign=2020-is-innovationperformance \&utm _content=commonlanguage-paidsearch-70140000000vhlSQAQ \&creative $=438871687604 \&$ keyword

59. D. Newton, Early Troubles in the Purdue, Kaplan Marriage, Forbes, 31 August 2019. [Online]. Available: https://www.forbes. com/sites/dereknewton/2019/08/31/early-troubles-in-the-purduekaplan-marriage/\#29ebc81f670d

60. A.J. Magda, The state of innovation in higher education: a survey of academic administrators (The Learning House, Inc., 2018). Available: https://olc-wordpress-assets.s3.amazonaws.com/ uploads/2018/04/The-State-of-Inn

61. M. Abreu, P. Demirel, V. Grinevich, M. Karataș-Özkan, Entrepreneurial practices in research-intensive and teaching-led universities. Small Business Econ. 695-717 (2016)

62. L. Armstrong, Higher education and the global marketplace: entrepreneurial activity in a dynamic environment (2004). [Online]. Available: https://www.academia.edu/30510908/Highe

63. W.G. Tierney, G.C. Hentschke, New players, different game: understanding the rise of for-profit colleges and universities (Johns Hopkins University Press, Baltimore, MD, 2007)

64. L. Armstrong, Barriers to innovation and change in higher education (TIAA-CREF Institute, 2014). Available:https://www academia.edu/9815901/Barriers_to_Innovation_and_Change_in_ Higher_Education

Open Access This chapter is licensed under the terms of the Creative Commons Attribution 4.0 International License (http:// creativecommons.org/licenses/by/4.0/), which permits use, sharing, adaptation, distribution and reproduction in any medium or format, as long as you give appropriate credit to the original author(s) and the source, provide a link to the Creative Commons license and indicate if changes were made.
65. W. Massy, Course level activity based costing as an academic and financial tool (TIAA Institute, 2016). Available: https://www. tiaainstitute.org/sites/default/files/presentations/2017-02/institute_ series_course_level_activity_based_costing

66. E. Zimmerman, What can real-time data analytics do for higher education?EdTech Focus on Higher Education, 29 August 2019. [Online]. Available: https://edtechmagazine.com/higher/article/ 2019/08/what-can-real-time-data-analytics-do-higher-education-perfcon

67. K. Walker, RCM reality check: one study of responsibility centered management underscores the need to address crucial concerns prior to implementation,Business Officer, November, 2019. Available: https://businessofficermagazine.org/features/rcmreality-check/

68. L. Cassuto, Scholars, know thy history: higher ed has always struggled to survive in the U.S., The Chronicle of Higher Education, 17 July 2018. Available: https://www.chronicle.com/ article/Scholars-Know-Thy-History-/243942

69. J. Fowles, Funding and focus: resource dependence in public higher education. Res. High. Educ. 55(3), 272-287 (2014)

Prof. Guilbert C. Hentschke Serving for more than 50 years in administrative, academic, and advisory positions, all focused on education, Hentschke is currently dean emeritus at the University of Southern California's Rossier School of Education, where he served as dean (1988-2000) and professor. In 2010 Hentschke was awarded a Fulbright Scholarship to serve as visiting professor at King Saud University. In 2014 he joined EY-Parthenon, the newly formed education division of Ernst and Young, as Senior Advisor. Prior to joining USC in 1988 he served as dean of the (now) Warner School of Education at the University of Rochester. He has also served in academic and administrative capacities at Columbia University's Teachers College, Chicago Public Schools, and Eastside Union High School District (CA). His research and writing focus on the finance, governance, and policies of education organizations, resulting in numerous books (e.g., Strategic Mergers in Higher Education, New Players, Different Game: Understanding the Rise of For-Profit Colleges and Universities) and other publications (e.g., "The Business of Education: Social Purposes, Market Forces and the Changing Organization of Schools"). Many of these publications have been co-authored with numerous colleagues.Throughout his career Hentschke has served on multiple commissions and boards of directors. Current active service includes: WestEd (past president), California Credit Union (Chair, Supervisory Committee), and Excellent Education Development (ExED). He earned his bachelor's degree in history and economics at Princeton University and his masters and doctorate in education and business at Stanford University.

The images or other third party material in this chapter are included in the chapter's Creative Commons license, unless indicated otherwise in a credit line to the material. If material is not included in the chapter's Creative Commons license and your intended use is not permitted by statutory regulation or exceeds the permitted use, you will need to obtain permission directly from the copyright holder. 